\title{
Nanoemulsion containing essential oil from Xylopia ochrantha Mart. produces molluscicidal effects against different species of Biomphalaria (Schistosoma hosts)
}

\author{
Fernanda de Paula Araújo ${ }^{1,5}$, Ricardo Diego Duarte Galhardo de Albuquerque ${ }^{1 /+}$, \\ Leonardo da Silva Rangel ${ }^{2,3,5}$, Gabriel Rocha Caldas', Luís Armando Cândido Tietbohl', \\ Marcelo Guerra Santos ${ }^{4}$, Eduardo Ricci-Júnior 6 , Silvana Thiengo ${ }^{7}$, Monica Ammon Fernandez ${ }^{7}$, \\ José Augusto Albuquerque dos Santos ${ }^{2}$, Robson Xavier Faria ${ }^{3,5}$, Leandro Rocha ${ }^{1,5}$ \\ ${ }^{1}$ Universidade Federal Fluminense, Laboratório de Tecnologia de Produtos Naturais, Niterói, RJ, Brasil \\ ${ }^{2}$ Fundação Oswaldo Cruz-Fiocruz, Instituto Oswaldo Cruz, Laboratório de Avaliação e Promoção da Saúde Ambiental, Rio de Janeiro, RJ, Brasil \\ ${ }^{3}$ Fundação Oswaldo Cruz-Fiocruz, Instituto Oswaldo Cruz, Laboratório de Toxoplasmose e Outras Protozooses, Rio de Janeiro, RJ, Brasil \\ ${ }^{4}$ Universidade do Estado do Rio de Janeiro, Faculdade de Formação de Professores, Departamento de Ciências, Rio de Janeiro, RJ, Brasill \\ ${ }^{5}$ Universidade Federal Fluminense, Programa de Pós-Graduação em Ciências e Tecnologia, Niterói, RJ, Brasil \\ ${ }^{6}$ Universidade Federal do Rio de Janeiro, Centro de Ciências da Saúde, Departamento de Medicamentos, Rio de Janeiro, RJ, Brasil \\ ${ }^{7}$ Fundação Oswaldo Cruz-Fiocruz, Instituto Oswaldo Cruz, Laboratório de Malacologia, Rio de Janeiro, RJ, Brasil
}

BACKGROUND This work describes a chemical study of the essential oil from leaves of Xylopia ochrantha, an endemic Annonaceae species from Brazil, and its activity against Biomphalaria species. Considering its poor solubility in aqueous medium, the essential oil was nanoemulsified to evaluate its action on controlling some mollusc species of genus Biomphalaria, snail hosts of Schistosoma mansoni that causes schistosomiasis, which mainly affects tropical and subtropical countries.

OBJECTIVES The main aims of this work were to analyse the chemical composition of essential oil from $X$. ochrantha, and to evaluate the effect of its nanoemulsion on molluscs of genus Biomphalaria and their oviposition.

METHODS Chemical analysis was performed by gas chromatography coupled to mass spectrometry. Nanoemulsions were prepared by a low energy method and characterised by particle size and polydispersity index. Biological assays evaluating the mortality of adult species of $B$. glabrata, B. straminea and B. tenagophila and their ovipositions upon contact with the most stable nanoemulsion during 24 and $48 \mathrm{~h}$ were performed.

FINDINGS Chemical analysis by mass spectrometry revealed the majority presence of bicyclogermacrene and germacrene D in the essential oil. The formulation with a hydrophilic-lipophilic balance (HLB) of 9.26 was the most suitable for the oil delivery system. This nanoemulsion caused the mortality in B. tenagophila, B. straminea and B. glabarata of different sizes at levels ranging from 50 to $100 \%$ in $48 \mathrm{~h}$. Additionally, the formulation could inhibit the development of deposited eggs.

CONCLUSION Thus, these results suggest the use of nanoemulsified essential oil from $X$. ochrantha as a possible alternative in controlling some Biomphalaria species involved in the schistosomiasis cycle.

Key words: essential oil nanoemulsion - Xylopia ochrantha - mollusc control - Biomphalaria - schistosomiasis

Schistosomiasis is an acute and chronic parasitic disease caused by trematode worms of the genus Schistosoma and is transmitted by several types of snails. It affects people along 78 countries mainly in tropical and subtropical regions. Schistosomiasis is the second largest infectious-parasitic disease in the world after malaria. In 2014, at least 61.6 million people in the world have been treated for schistosomiasis. ${ }^{(1)}$ The acute form of this disease causes symptoms like fever, fatigue, myalgia, malaise, non-productive cough, whereas later stages show abdominal pathologies such as diarrhoea, diffuse abdominal pain, and hepatosplenomegaly. A chronic condition occurs when Schistosoma deposits its eggs and reactions

doi: 10.1590/0074-02760180489

Financial support: This study was financed in part by the CAPES

(Finance Code 001).

+ Corresponding author: ricardo-diego-cf@hotmail.com

(D) http://orcid.org/0000-0002-8442-3849

Received 15 October 2018

Accepted 21 February 2019 from the host immune system lead to urinary, intestinal, hepatic, and ectopic forms of the disease. ${ }^{(2)}$

Human schistosomiasis is caused by Schistosoma mansoni that uses molluses of genus Biomphalaria as its intermediate host. In many cases, prevention methods like Biomphalaria and Oncomelania eradication using chemical pesticides are relevant to control the disease. Niclosamide (Bayluscide, Bayer, Leverkusen, Germany) is the only commercially available molluscicide recommended by the World Health Organization (WHO) for large-scale use in Schistosomiasis Control Programs. ${ }^{(3)}$ However, this drug is toxic to other organisms, and resistance to niclosamide requires a search for new drugs and substances to be used in the vector control. ${ }^{(4)}$ Therefore, the WHO encourages a search for alternative drugs in schistosomiasis control. Natural products can be seen as a promising alternative as they are plentiful in schistosomiasis-endemic countries and have a large number of different substances in their extracts, which hinders the appearance of vectors-resistance. ${ }^{(5)}$ 
Essential oils are used to the control of snails, and plant species with high yields of essential oil as from genus Xylopia, showed activity against Biomphalaria glabrata, a relevant intermediate host of $S$. mansoni. (6) However, essential oils have low solubility in water, which may compromise their activity against Biomphalaria. Therefore, they must be processed into a formulation capable of viable use in biological activity studies. Nanotechnology has been used to solve problems of hydrosolubility and stability for active substances. There are several nanocarriers of drugs including nanoparticles, liposomes, and nanoemulsions (NEs). (7)

Nanoemulsions have been widely used as nanocarriers of hydrophobic drugs and essential oils. The majority of NEs are dispersions of nanometric oil droplets in water stabilized by surfactants. The droplet size of a nanoemulsion is typically in the range of 20-200 $\mathrm{nm} .{ }^{(8,9)}$ Some key advantages of these nanocarriers are easy preparation, simple composition, the possibility of industrial-scale production, low cost of production, and high thermodynamic stability. ${ }^{(10,11)}$

Xylopia ochrantha Mart. is an endemic Annonaceae species from Brazil and is popularly known as "imbiúprego". There is little information regarding the chemical, pharmaceutical, and biological activities from this species. ${ }^{(12,13)}$ Thus, this work aimed to identify the chemical composition of essential oil from $X$. ochrantha leaves and to evaluate the activity of a nanoemulsion produced with this oil on the developmental stages (oviposition) and mortality of different Biomphalaria species.

\section{MATERIALS AND METHODS}

Plant material - Three specimens of X. ochrantha Mart., Annonaceae, were collected at Restinga de Jurubatiba National Park (RJ), Brazil, in Clusia scrub

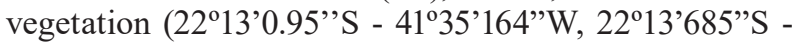
$\left.41^{\circ} 35^{\prime} 256^{\prime \prime} \mathrm{W}, 22^{\circ} 12^{\prime} 420^{\prime \prime} \mathrm{S}-41^{\circ} 36^{\prime} 354^{\prime \prime} \mathrm{W}\right)$ during the day on July 27,2016 . This species was identified by botanist Dr Santos MG and a voucher specimen was deposited at the Faculdade de Formação de Professores herbarium (Universidade do Estado do Rio de Janeiro, Brazil) under registration number RFFP 14.500.

Extraction of essential oil - A mixture of leaves $(1000 \mathrm{~g})$ from the three specimens collected was turbolised with distilled water. The material was then placed in a five $\mathrm{L}$ bottom flask and subjected to hydrodistillation for $4 \mathrm{~h}$ in a Clevenger-type apparatus. In the end, the oils were collected and stored at $4^{\circ} \mathrm{C}$ for further analyses.

Gas chromatography/mass spectrometry analysis - The essential oil recovered was analysed using a GCMS-QP5000 (Shimadzu) gas chromatograph, equipped with a mass spectrometer using electron ionisation. Gas chromatographic (GC) conditions were as follows: injector temperature, $260^{\circ} \mathrm{C}$; flame ionisation detection (FID) temperature, $290^{\circ} \mathrm{C}$; carrier gas, Helium; flow rate, $1 \mathrm{~mL} /$ min; and split injection with split ratio 1:40. The oven temperature was initially $60^{\circ} \mathrm{C}$ and was increased to $290^{\circ} \mathrm{C}$ at a rate of $3^{\circ} \mathrm{C} / \mathrm{min}$. One microliter of each sample, dissolved in dichloromethane $(1: 100 \mathrm{mg} / \mu \mathrm{L})$, was injected into a DB-5 column $(0.25 \mathrm{~mm}$ I.D, $30 \mathrm{~m}$ in length, and $0.25 \mu \mathrm{m}$ film thickness). Mass spectrometry (MS) electron ionisation was at $70 \mathrm{eV}$ and scan rate was $1 \mathrm{scan} / \mathrm{s}$. Retention indices (RI) were calculated by extrapolating the retention times of a mixture of aliphatic hydrocarbons $\left(\mathrm{C}_{9}-\mathrm{C}_{30}\right)$ analysed under the same conditions. ${ }^{(14)}$ Substances were identified by comparing their retention indices and mass spectra with those reported in literature. ${ }^{(15)}$ The MS fragmentation pattern of compounds was also compared with NIST mass spectra libraries. Quantitative analysis of the chemical constituents was performed by flame ionisation gas chromatography (CG/FID), under the same conditions as $\mathrm{GC} / \mathrm{MS}$ analysis. Percentages of these compounds were obtained by FID peak area normalisation method.

Nanoemulsification method and determination of hydrophilic-lipophilic balance (HLB) - Emulsification was performed by modification of the low energy method described by Ostertag et al. ${ }^{(16)}$ Emulsions comprised 5\% $(\mathrm{w} / \mathrm{w})$ of $X$. ochrantha oil, $5 \%(\mathrm{w} / \mathrm{w})$ of surfactants, and $90 \%(\mathrm{w} / \mathrm{w})$ water. Tween 20 and Span 80 were used as surfactants to prepare the nanoemulsions. Various emulsions with HLB values ranging from 4.3 to 16.7 were prepared by mixing the surfactants in different proportions. For preparation of nanoemulsions, oily phase constituted by $X$. ochrantha oil and surfactants was homogenised by magnetic stirring (400 rpm) for $30 \mathrm{~min}$ at room temperature. After this, the aqueous phase (distilled water) was added to the oily phase under the same continuous magnetic stirring $(400 \mathrm{rpm})$ for $1 \mathrm{~h}$. The formulations were analysed to verify their stability by analysis of droplet size and polydispersity index values. The formulation with the lowest values of droplet size and polydispersity index indicated the adequate oil HLB.

Nanoemulsion characterisation - Droplet size and polydispersity index (PDI) of the nanoemulsions were determined by photon correlation spectroscopy (Zetasizer ZS, Malvern, UK). Droplet measurements were performed in triplicate and average droplet size was expressed as the mean diameter \pm standard deviation.

Molluscicidal assays - Nanoemulsion of essential oil from $X$. ochrantha $(100 \mathrm{ppm})$ was diluted to three different concentrations ( $80 \mathrm{ppm}, 60 \mathrm{ppm}$, and $40 \mathrm{ppm}$ ) in distilled water. For the assay, 10 adult snails of B. glabrata species (measuring 10-12 $\mathrm{mm}$ diameter, from Sumidouro, RJ, Brazil) were exposed to $2 \mathrm{~mL}$ of the nanoemulsion, in a 24-well plate for $48 \mathrm{~h}$ at room temperature, according to the bioassay adapted from WHO, $1983^{(17)}$ (Fig. 1). Adult snails free of $S$. mansoni infection were kept in breeding grounds at the Laboratory for Analysis and Promotion of Environmental Health (LAPSA/IOC). Snail mortality was recorded over the following $48 \mathrm{~h}$, and was compared with the nanoformulation control (formulation without oil at $100 \mathrm{ppm}$ ), positive control [Bayluscide WP 70® (Niclosamide) at $1 \mathrm{ppm}$ ], and negative control (distilled water). Absence of snail retraction into their shells after stimulation of the cephalopodal mass and/or release of haemolymph were the criteria of death. These assays were performed in triplicate.

Complementary assessments of mortality and inhibition of posture development were performed with $B$. 


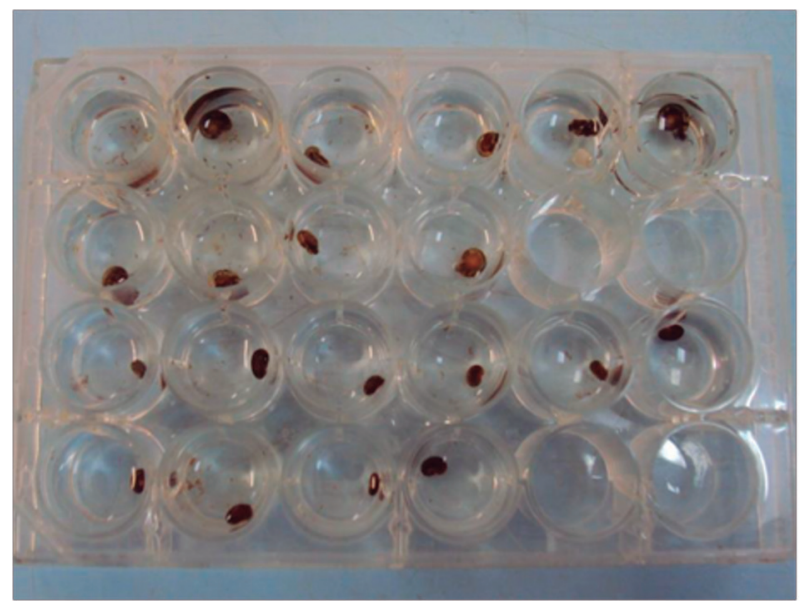

Fig. 1: a 24-well plate divided into two groups of ten Biomphalaria molluscs.

straminea, B. tenagophila, and B. glabrata from other locations (Ressaca, Belo Horizonte, MG, Brazil). For each analysis of mortality, according to a previous protocol, $2 \mathrm{~mL}$ of the $\mathrm{DL}_{25}, \mathrm{DL}_{50}$, and $\mathrm{DL}_{90}$ sample concentrations obtained in the previous analysis with $B$. glabrata were used, and the groups of molluscs were divided into 10 individuals, and were separated according to size (3-5 $\mathrm{mm}, 4-6 \mathrm{~mm}$, and $8-10 \mathrm{~mm})$. Analysis of postures viability of $B$. glabrata (Ressaca, MG) was performed by treating them (two and five days old) with $2 \mathrm{~mL}$ of $\mathrm{DL}_{25}$, $\mathrm{DL}_{50}$, and $\mathrm{DL}_{90}$ sample concentrations, and counting the number of eggs that were not viable in relation to the initial amount, at 24 and $48 \mathrm{~h}$ (Fig. 2). As in the previous assay, the results were compared with the positive, negative, and nanoformulation controls.

Concentrations that killed $50 \%$ and $90 \%\left(\mathrm{LC}_{50}\right.$ and $\mathrm{LC}_{90}$ ) of the exposed snails in $24 \mathrm{~h}$ and $48 \mathrm{~h}$ (compared with the negative-control cultures) were expressed as the mean and standard deviation, and were statistically analysed using Student's $t$-test $(\mathrm{p} \leq 0.05)$, using the software R (MASS data package).

\section{RESULTS}

Essential oil - Essential oil obtained from fresh leaves $(2.0 \mathrm{~g})$ showed a bright green colour and a yield of $0.2 \%$. Oil density was $0.8 \mathrm{~g} / \mathrm{mL}$ and $\mathrm{pH}$ was equal to 5.0 . In total, 27 substances were identified with the predominance of sesquiterpenes and hydrocarbons $(68.55 \%)$. The main substances found in these analyses were bicyclogermacrene (25.18\%), and germacrene D (20.90\%). Substances such as $\beta$-pinene $(8.07 \%)$, sylvestrene $(6.50 \%)$, and E-caryophyllene (6.23\%) were also present (Table I).

Nanoemulsion - The droplet size and PDI were used to select the HLB of the NE (Table II). The formulation with a HLB of 9.26 (40\% of Tween 20 and $60 \%$ of Span 80 ), showed values of droplet size as $114 \pm 1 \mathrm{~nm}$ and a PDI of $0.1 \pm 0.0$, which in turn, are characteristic of a stable nanoemulsion. The selected NE exhibited a translucent and homogeneous appearance.

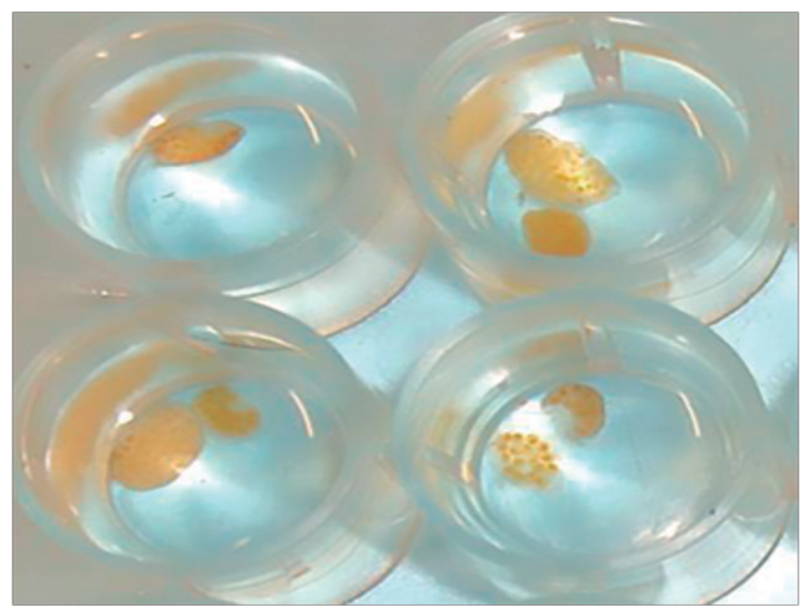

Fig. 2: egg postures of Biomphalaria species in extended size.

TABLE I

Chemical composition of essential oil of leaves from Xylopia ochrantha (Mart.)

\begin{tabular}{|c|c|c|c|}
\hline AI lit & AI exp & Substance & $(\%)$ \\
\hline 932 & 934 & a-pinene & 2.7 \\
\hline 969 & 974 & sabinene & 1.0 \\
\hline 974 & 978 & $\beta$-pinene & 8.1 \\
\hline 1002 & 1007 & a-phellandrene & 0.7 \\
\hline 1022 & 1026 & o-cymene & 0.9 \\
\hline 1025 & 1030 & sylvestrene & 6.5 \\
\hline 1032 & 1037 & Z- $\beta$-ocimene & 0.4 \\
\hline 1044 & 1048 & E- $\beta$-ocimene & 1.3 \\
\hline 1335 & 1340 & $\delta$-elemene & 5.4 \\
\hline 1374 & 1378 & a-copaene & 2.3 \\
\hline 1389 & 1395 & $\beta$-elemene & 2.4 \\
\hline 1417 & 1423 & E-caryophyllene & 6.2 \\
\hline 1434 & 1436 & $\lambda$-elemene & 0.5 \\
\hline 1452 & 1452 & cis muurola-3,5-diene & 0.6 \\
\hline 1452 & 1458 & a-humulene & 0.8 \\
\hline 1458 & 1465 & allo-aromadendrene & 0.6 \\
\hline 1478 & 1481 & $\lambda$-muurolene & 1.0 \\
\hline 1480 & 1486 & germacrene D & 20.9 \\
\hline 1500 & 1502 & bicyclogermacrene & 25.2 \\
\hline 1506 & 1505 & a-bisabolene & 0.4 \\
\hline 1522 & 1528 & $\delta$-cadinene & 0.9 \\
\hline 1559 & 1562 & germacrene B & 1.4 \\
\hline 1577 & 1586 & spathulenol & 4.0 \\
\hline 1590 & 1591 & globulol & 0.8 \\
\hline 1592 & 1600 & viridiflorol & 0.5 \\
\hline 1649 & 1659 & $\beta$-eudesmol & 0.7 \\
\hline \multirow[t]{5}{*}{1652} & 1663 & a-cadinol & 0.5 \\
\hline & & Total identified & 96.6 \\
\hline & & Monoterpeneshydrocarbons & 21.6 \\
\hline & & Sesquiterpeneshydrocarbons & 68.6 \\
\hline & & Oxygenatedsesquiterpenes & 6.5 \\
\hline
\end{tabular}




\section{TABLE II}

Size droplet, polydispersity index (PDI) and hydrophilic-lipophilic balance (HLB) values of eleven formulations with essential oil from Xylopia ochrantha

\begin{tabular}{lccc}
\hline Formulation & Sizedroplet $(\mathrm{nm})$ & PDI & HLB \\
\hline F1 & $329 \pm 19$ & $0.3 \pm 0.2$ & 16.70 \\
F2 & $232 \pm 4$ & $0.3 \pm 0.0$ & 15.46 \\
F3 & $168 \pm 3$ & $0.3 \pm 0.0$ & 14.22 \\
F4 & $142 \pm 3$ & $0.2 \pm 0.0$ & 12.98 \\
F5 & $112 \pm 1$ & $0.3 \pm 0.0$ & 11.74 \\
F6 & $114 \pm 1$ & $0.2 \pm 0.0$ & 10.50 \\
F7 & $114 \pm 1$ & $0.1 \pm 0.0$ & 9.26 \\
F8 & $187 \pm 1$ & $0.3 \pm 0.0$ & 8.02 \\
F9 & $227 \pm 4$ & $0.2 \pm 0.0$ & 6.78 \\
F10 & $386 \pm 13$ & $0.2 \pm 0.0$ & 5.54 \\
F11 & $323 \pm 2$ & $0.3 \pm 0.0$ & 4.30 \\
\hline
\end{tabular}

\section{Molluscicidal assays}

Effects on B. glabrata juvenile and adults from Sumidouro and Ressaca regions - Molluscicidal activity was tested in juveniles (size of 3-5 mm), adults with 6-7 mm, and adults with 8-10 $\mathrm{mm}$. Additionally, these specimens were collected from two regions, Sumidouro (RJ, Brazil) and Ressaca (MG, Brazil).

Lethal concentrations obtained from B. glabrata (Sumidouro, RJ) were used to test against B. glabrata (Ressaca, MG) of different age/size, and against other Biomphalaria species. Additionally, the same lethal concentrations were used in oviposition tests on Biomphalaria.

Nanoemulsion (NE) of the essential oil from $X$. ochrantha leaves exhibited molluscicidal activity against adult (size of 10-12 mm) B. glabrata (Sumidouro, RJ) with $\mathrm{LC}_{50} / 24 \mathrm{~h}=50.91 \pm 3.06 \mathrm{ppm}, \mathrm{LC}_{90} / 24 \mathrm{~h}=85.46 \pm$ $4.96 \mathrm{ppm}, \mathrm{LC}_{50} / 48 \mathrm{~h}=47.41 \pm 2.85 \mathrm{ppm}$, and $\mathrm{LC}_{90} / 48 \mathrm{~h}$ $=78.48 \pm 4.35 \mathrm{ppm}$. Furthermore, in the complementary assay with $B$. glabrata (Ressaca, MG), NE was tested at three concentrations 32,47 , and $78 \mathrm{ppm}$. Among juvenile molluscs with a size of $3-5 \mathrm{~mm}, 96.7 \%$ and $100 \%$ mortality was observed at the concentrations of $47 \mathrm{ppm}$ $\left(\mathrm{LC}_{90} / 48 \mathrm{~h}\right)$ and $78 \mathrm{ppm}\left(\mathrm{LC}_{50} / 48 \mathrm{~h}\right)$, respectively, within $24 \mathrm{~h}$. The NE could cause a higher mortality rate among adults of size $6-7 \mathrm{~mm}(100 \%$ at the concentration of 47 $\mathrm{ppm})$. When it was used at a concentration of $32 \mathrm{ppm}$, the NE caused mortality in $96.7 \%$ adults from this region. Adult molluscs (between $8-10 \mathrm{~mm}$ ) were affected to a lesser extent, exhibiting mortality of $3.3 \%$ in $24 \mathrm{~h}$ at the concentration of $47 \mathrm{ppm}$ (Table III).

NE treatment for $48 \mathrm{~h}$ basically maintained the results observed after $24 \mathrm{~h}$ (Table IV) for all sizes of $B$. glabrata (Ressaca, MG) tested.

Effects on B. straminea adults - As in the evaluations on $B$ glabrata (Ressaca, MG), NE caused mortality in molluscs of 3-5 $\mathrm{mm}$ in the range of $100 \%$ and $90 \%$ in 24 $\mathrm{h}$ when used at concentrations of 78 and $32 \mathrm{ppm}$, respectively. Adults of size 6-7 mm exhibited higher mortality of $100 \%$ at the concentration of $47 \mathrm{ppm}$ and $93.3 \%$ at the concentration of $32 \mathrm{ppm}$, within $24 \mathrm{~h}$. NE at the concentration of $47 \mathrm{ppm}$ was evaluated in molluscs of $8-10 \mathrm{~mm}$, which caused mortality in the range of $46.7 \%$ at $24 \mathrm{~h}$.

NE treatment for $48 \mathrm{~h}$ in molluscs of $3-5 \mathrm{~mm}$ treated with 78 and $32 \mathrm{ppm}$ caused $100 \%$, and $93.3 \%$ mortality, respectively. When treated for $48 \mathrm{~h}$, molluscs of 6-7 mm showed $100 \%$ mortality in the presence of $47 \mathrm{ppm}$ NE (Figs 3,4). Molluscs of 8-10 mm showed mortality in the range of $100 \%$ when treated with $47 \mathrm{ppm}$ (Table IV).

Effects on B. tenagophila adults - At the highest concentration tested (78 ppm), molluscs of 3-5 $\mathrm{mm}$ were totally affected after $24 \mathrm{~h}$, with $100 \%$ mortality. Molluscs of 6-7 mm also showed $100 \%$ mortality at $24 \mathrm{~h}$, when tested at the $47 \mathrm{ppm}$ concentration. In this same period, $32 \mathrm{ppm}$ NE caused $96.7 \%$ mortality. In larger molluscs $(8-10 \mathrm{~mm}), 47 \mathrm{ppm}$ NE caused a mortality rate of $26.7 \%$ in $24 \mathrm{~h}$ (Table III).

TABLE III

Mortality index (in percentage) of different Biomphalaria species in different sizes/ages treated with the nanoemulsionated essential oil from Xylopia ochrantha in $24 \mathrm{~h}$

\begin{tabular}{lcccccc}
\hline & $32 \mathrm{ppm}$ & $47 \mathrm{ppm}$ & $78 \mathrm{ppm}$ & Positive control & Nano control & Negative control \\
\cline { 2 - 6 } mollusks & & & $(\%)$ mortality $(24 \mathrm{~h})$ & \\
\hline B. straminea $(3-5 \mathrm{~mm})$ & - & 90 & 100 & 100 & 0 & 0 \\
B. tenagophila $(3-5 \mathrm{~mm})$ & - & 100 & 100 & 100 & 0 & 0 \\
B. glabrata $(3-5 \mathrm{~mm})$ & - & 96.7 & 100 & 100 & 0 & 0 \\
B. straminea $(6-7 \mathrm{~mm})$ & 93.3 & 100 & - & 100 & 0 & 0 \\
B. tenagophila $(6-7 \mathrm{~mm})$ & 96.7 & 100 & - & 100 & 0 & 0 \\
B. glabrata $(6-7 \mathrm{~mm})$ & 96.7 & 100 & - & 100 & 0 & 0 \\
B. straminea $(8-10 \mathrm{~mm})$ & - & 46.7 & - & 100 & 0 & 0 \\
B. tenagophila $(8-10 \mathrm{~mm})$ & - & 26.7 & - & 100 & 0 & 0 \\
B. glabrata $(8-10 \mathrm{~mm})$ & - & 3.3 & - & & 0
\end{tabular}




\section{TABLE IV}

Mortality index (in percentage) of different Biomphalaria species in different sizes/ages treated with the nanoemulsionated essential oil from Xylopia ochrantha in $48 \mathrm{~h}$

\begin{tabular}{|c|c|c|c|c|c|c|}
\hline \multirow[b]{2}{*}{ mollusks } & $32 \mathrm{ppm}$ & $47 \mathrm{ppm}$ & $78 \mathrm{ppm}$ & Positive control & Nano control & Negative control \\
\hline & \multicolumn{6}{|c|}{$(\%)$ mortality (48 h) } \\
\hline B. straminea $(3-5 \mathrm{~mm})$ & - & 93.3 & 100 & 100 & 0 & 0 \\
\hline B. tenagophila $(3-5 \mathrm{~mm})$ & - & 100 & 100 & 100 & 0 & 0 \\
\hline B. glabrata $(3-5 \mathrm{~mm})$ & - & 96.7 & 100 & 100 & 10 & 20 \\
\hline B. straminea $(6-7 \mathrm{~mm})$ & 100 & 100 & - & 100 & 0 & 0 \\
\hline B. tenagophila $(6-7 \mathrm{~mm})$ & 96.7 & 100 & - & 100 & 0 & 0 \\
\hline B. glabrata $(6-7 \mathrm{~mm})$ & 96.7 & 100 & - & 100 & 0 & 0 \\
\hline B. straminea $(8-10 \mathrm{~mm})$ & - & 100 & - & 100 & 0 & 0 \\
\hline B. tenagophila $(8-10 \mathrm{~mm})$ & - & 53.3 & - & 100 & 0 & 0 \\
\hline B. glabrata $(8-10 \mathrm{~mm})$ & - & 10 & - & 100 & 0 & 0 \\
\hline
\end{tabular}

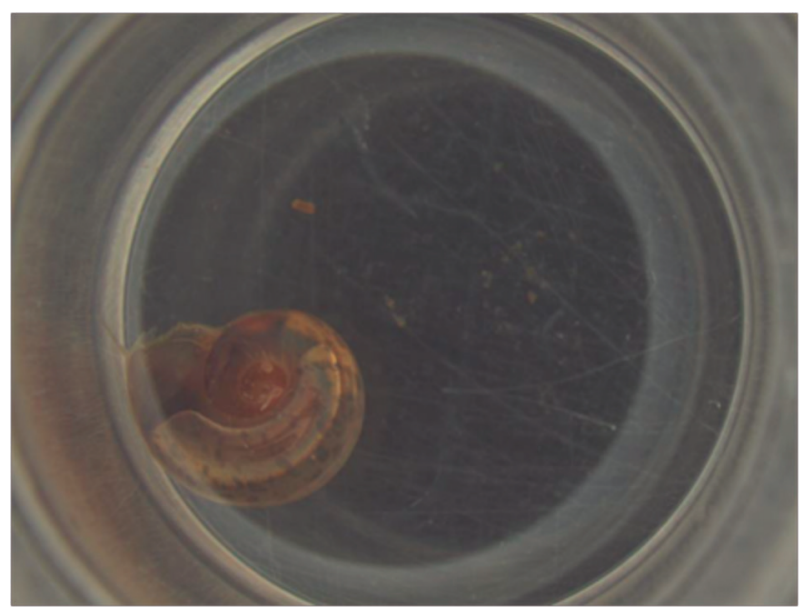

Fig. 3: Biomphalaria straminea in distilled water after $48 \mathrm{~h}$ (Photo: LRNEM/IOC).

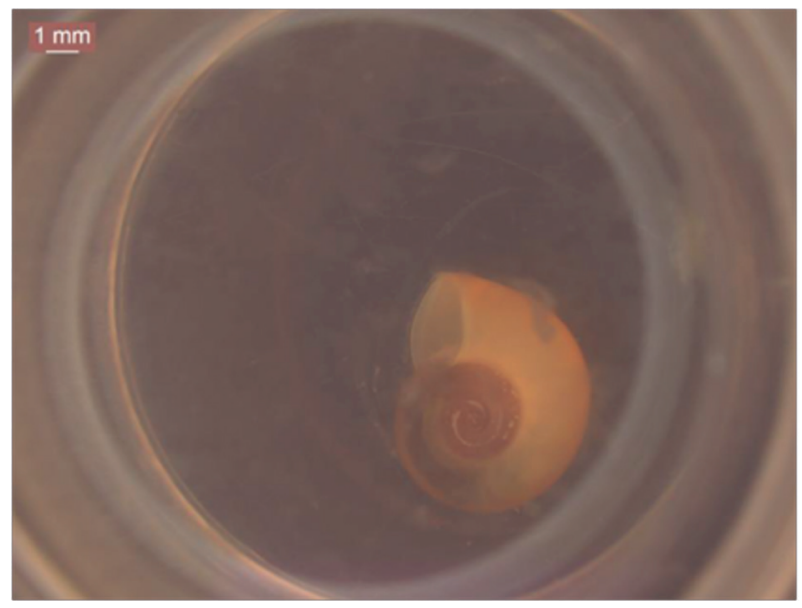

Fig. 4: Biomphalaria straminea dead in contact with $47 \mathrm{ppm}$ nanoemulsion (NE) after $48 \mathrm{~h}$ (Photo: LRNEM/IOC).
NE treatment for $48 \mathrm{~h}$ in molluscs of 3-5 $\mathrm{mm}$ and 6-7 mm caused $100 \%$ mortality in 47 ppm (Fig. 5). In molluscs of $8-10 \mathrm{~mm}$, the concentration of $47 \mathrm{ppm}$ resulted in $53.3 \%$ mortality (Tables IV).

In all these analyses, the positive control was fully effective for the three species in all sizes. NE free of essential oil did not cause mortality.

Effects on eggs posture development - In the analysis of eggs posture, NE was able to render the eggs from recent oviposition (two days) unfeasible in a period of 24 h with $100 \%$ inhibition for B. straminea, B. tenagophila, and $B$. glabrata (Ressaca, MG) at both concentrations (47 and $72 \mathrm{ppm}$ ) tested (Table V).

The five days old oviposition treated with $47 \mathrm{ppm}$ NE showed $91.7 \%$ unviable eggs after $24 \mathrm{~h}$ of treatment in $B$. straminea molluscs. At the concentration of 78 ppm, a reduction of the effect in B. straminea $(17.3 \%)$ was observed. The molluscs $B$. tenagophila treated with 47 ppm exhibited 49.4\% unviable eggs, and $78 \mathrm{ppm}$ caused a greater effect with $82.5 \%$ unviable eggs in $24 \mathrm{~h}$.

The molluscs $B$. glabrata (Ressaca, MG) showed $62.7 \%$ unviable eggs with $47 \mathrm{ppm}$, and $73.5 \%$ with 78 ppm for the same egg stage and time (Table V).

In $48 \mathrm{~h}$, all species eggs at two days were rendered unfeasible (Table VI). When the eggs were observed at late oviposition (five days), NE caused the maximal effect on $B$. straminea and B. glabrata (Ressaca, MG). In late oviposition, $B$. tenaghofila at $47 \mathrm{ppm}$ and $78 \mathrm{ppm}$ showed $70.4 \%$ and $95.2 \%$ unviable eggs, respectively.

\section{DISCUSSION}

Bicyclogermacrene and germacrene D, two major substances of the leaf essential oil from $X$. ochrantha, are the main components in other species of the genus such as $X$. langsdorffiana A.St.-Hil. \& Tul., X. aethiopica (Dunal) A.Rich., and X. aromatica (Lam.) Mart. Furthermore, high occurrence of sesquiterpenes in foliar essential oil is also observed in these species. ${ }^{(6,18,19)}$ 


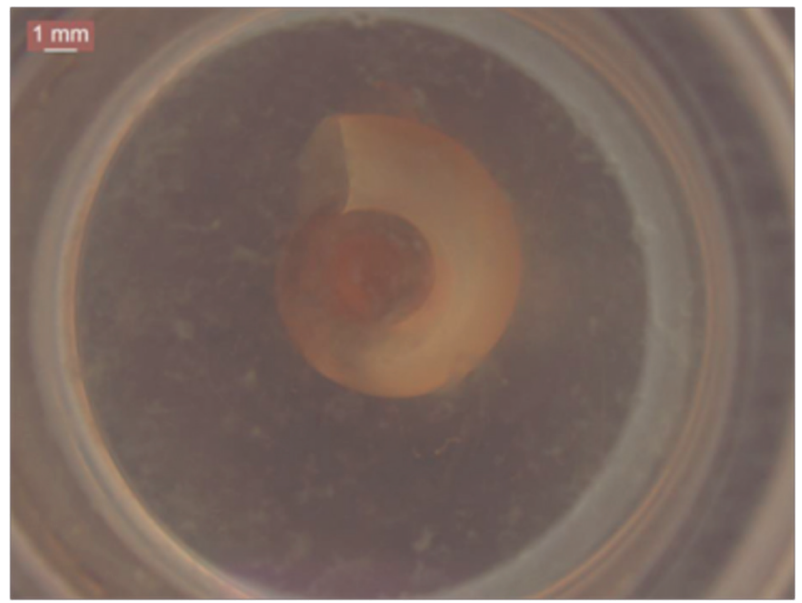

Fig. 5: Biomphalaria tenagophila dead in contact with 47 ppm nanoemulsion (NE) after $48 \mathrm{~h}$ (Photo: LRNEM/IOC).
The yield of leaf essential oil $(0.20 \%)$ is similar to that in other species of the genus, in a range from $0.07 \%$ and $0.43 \%$, relative to fresh leaves. . $^{(1,20,21)}$ Bicyclogermacrene is best known for its antimicrobial and fungicidal activities. ${ }^{(22,23,24)}$ Germacrene D is cited in literature as a simulator of insect pheromones, and is also involved in other important mechanisms of the insect-plant relationship. (25,26) Additionally, a previous study demonstrated molluscicidal activity from the leaf essential oil of $X$. langsdorffiana against $B$. glabrata, in which, germacrene D was the major compound.(6) This result can suggest an association with the activity found in the essential oil from $X$. ochrantha against $B$. glabrata, since these species are included in the same genus and have germacrene $\mathrm{D}$ as one of the two main constituents.

Although the constituents of essential oils from $X$. ochrantha are related to relevant biological activities, they have low solubility in water, which hinders their dispersion into the environment in aquatic media. Thus, delivery in aqueous carriers as nanoemulsions (NEs) is required. NEs were successfully produced using a low energy method of spontaneous emulsification. This

\section{TABLE V}

Inhibition of eggs development index (in percentage) of different species of Biomphalaria (two and five days old) after contacting with the nanoemulsionated essential oil from Xylopia ochrantha in $24 \mathrm{~h}$

\begin{tabular}{lccccc}
\hline & 47 ppm & 78 ppm & Positive control & Nano control & Negative control \\
\cline { 2 - 5 } mollusks & & & $(\%)$ unviable eggs (24 h) & 0 \\
\hline B. straminea (two days old) & 100 & 100 & 100 & 6.9 & 0 \\
B. tenagophila (two days old) & 100 & 100 & 100 & 2 & 0 \\
B. glabrata (two days old) & 100 & 100 & 83.3 & 0 & 0 \\
B. straminea (five days old) & 91.7 & 17.3 & 100 & 0 & 0 \\
B. tenagophila (five days old) & 49.4 & 82.3 & 100 & 0 & 0 \\
B. glabrata (five days old) & 62.7 & 73.5 & 100 & 0 \\
\hline
\end{tabular}

\section{TABLE VI}

Inhibition of eggs development index (in percentage) of different species of Biomphalaria (two and five days old) after contacting with the nanoemulsionated essential oil from Xylopia ochrantha in $48 \mathrm{~h}$

\begin{tabular}{|c|c|c|c|c|c|}
\hline \multirow[b]{2}{*}{ mollusks } & $47 \mathrm{ppm}$ & $78 \mathrm{ppm}$ & Positive control & Nano control & Negative control \\
\hline & \multicolumn{5}{|c|}{ (\%) unviable eggs (48 h) } \\
\hline B. straminea (two days old) & 100 & 100 & 100 & 6.9 & 0 \\
\hline B. tenagophila (two days old) & 100 & 100 & 100 & 45 & 0 \\
\hline B. glabrata (two days old) & 100 & 100 & 100 & 2 & 0 \\
\hline B. straminea (five days old) & 100 & 100 & 100 & 0 & 0 \\
\hline B. tenagophila (five days old) & 70.4 & 95.2 & 100 & 0 & 0 \\
\hline B. glabrata (five days old) & 100 & 100 & 100 & 0 & 0 \\
\hline
\end{tabular}


method is simple and only uses magnetic stirring. ${ }^{(8)}$ The aqueous phase was dripped over the organic phase under continuous magnetic stirring for $1 \mathrm{~h}$. The transition of surfactants from the oil phase to aqueous phase produces interfacial turbulence and spontaneous formation of nanometric oil droplets that are involved and stabilised by surfactants ${ }^{(27)}$ (Table II). The following criteria were used for the analysis and selection of the formulation: size $<200 \mathrm{~nm}$; PDI $<0.25$; and organoleptic characteristics: absence of phase separation and precipitation. The formulation with HLB of 9.26 (40\% of Tween 20 and $60 \%$ of Span 80 ) showed low values of droplet size and polydispersity index, which in turn, are characteristic of a nanoemulsion system. Development of a system to provide a suitable nanoformulation with a size below 200 $\mathrm{nm}$ for essential oil from $X$. ochrantha allows a more efficient aqueous dispersibility, stability, and delivery of actives in the target of action. NEs as delivery systems for essential oils permit interaction between the active principles and biological membranes. In general, this occurs through one of four main routes: 1-increased surface area and passive transport across the plasma membrane of cells; 2-fusion of the droplets with the cell membrane occurring specifically upon delivery of the substances at the site of action; 3-reservoir effect with sustained release of essential oil; 4-electrostatic interaction between positively charged droplets and negatively charged biological membrane favouring bioadhesion and biological effects. ${ }^{(8)}$ These facts highlight the relevance of bionanotechnology as an effective alternative for the control of diseases through inhibition of intermediate hosts of parasites present in the environment. Moreover, the biodegradability of the formulation is another factor that minimises residual toxicity problems of molluscicidal agents to the environment.

Molluscicidal activity of the nanoemulsion containing the essential oil from $X$. ochrantha against Biomphalaria molluscs could be observed in all evaluated species, including individuals of different ages/sizes and at different stages of egg development. According to the observed effects on mortality of B. glabrata of size $10-12 \mathrm{~mm}$ (Sumidouro, RJ), the $\mathrm{LC}_{90} / 24 \mathrm{~h}(85.46 \mathrm{ppm})$ of the oil is considered satisfactory, as the value recommended by the WHO for a plant sample to be considered active is $\mathrm{DL}_{90} / 48 \mathrm{~h}<100 \mathrm{ppm} .{ }^{(3)}$ Differences in action on individuals of different species could be observed, so that comparing the NE concentration (47 ppm) at $24 \mathrm{~h}$, B. tenaghofila appeared to be more susceptible to NE, though all species with sizes of 3-5 $\mathrm{mm}$ and 6-7 $\mathrm{mm}$ presented a high mortality rate. Adult individuals of $B$. glabrata $(8-10 \mathrm{~mm})$ exhibited resistance. Treatment for 48 $\mathrm{h}$ at the concentration of $47 \mathrm{ppm}$ caused an effect similar to that at $24 \mathrm{~h}$. In contrast to old specimens $(8-10 \mathrm{~mm})$ that increased the susceptibility at $B$. straminea.

Another observation can be noted when comparing the sizes of individuals within the same species, wherein smaller/younger molluscs were found to be less resistant to NE action, suggesting that older individuals may have a more developed resistance system against the active components of NE.
NE also acts on oviposition with an inhibitory effect at the concentrations of $47 \mathrm{ppm}$ and $78 \mathrm{ppm}$. All eggs, from more recent oviposition (two days), presented $100 \%$ mortality in $24 \mathrm{~h}$. In eggs from older oviposition (five days), $100 \%$ inhibition of development was observed only in a period of $48 \mathrm{~h}$, although inhibition was also observed at $24 \mathrm{~h}$, at varying degrees. These results suggest a higher resistance to oil compounds by the more developed eggs of $B$. tenaghofila species.

Finally, these biological assays demonstrated the molluscicidal activity of the nanoemulsified essential oil from $X$. ochrantha and the inhibition of different stages of development in Biomphalaria molluscs, which denotes the biological importance of a species with poor scientific information regarding controlling disease transmitters.

In conclusion - This study reported the molluscicidal activity and chemical composition of essential oil from leaves of $X$. ochrantha, a Brazilian endemic species. This is the first report on the activity of this species in the control of molluscs that are part of infectious diseases cycles, more specifically against Biomphalaria that are involved in the transmission of schistosomiasis. Thus, this result suggests the use of nanoemulsified essential oil from $X$. ochrantha as a promising alternative for Biomphalaria control, as this plant species is endemic to a country affected by schistosomiasis.

\section{ACKNOWLEDGEMENTS}

To Henrique dos Santos Almeida for statistical analysis.

\section{AUTHORS' CONTRIBUTION}

FPA, RDDGA, LSR, MAF and JAAS performed the biological experiments; ST, MAF, JAAS and RXF were responsible for the development of biological experiments; GRC worked on the nanoemulsion activities; RDDGA wrote the manuscript and performed the chemical analysis; RXF, ER and LACT reviewed the manuscript; MG collected the plant material and performed the botanical identification; LR coordinated the overall project. All authors have read and approved the manuscript. The authors declare no conflicts of interest.

\section{REFERENCES}

1. WHO - World Health Organization. Epidemiology and control of schistosomiasis. Technical report series 728. Geneva: WHO; 2016.

2. Colley DG, Bustinduy AL, Secor WE, King CH. Human schistosomiasis. Lancet. 2014; 383(9936): 2253-64.

3. WHO - World Health Organization. Organization's guidelines on screening for plant molluscicides. Technical report series 728 . Geneva: WHO; 1983.

4. Inobaya MT, Olveda RM, Chau TNP, Olveda DU, Ross AGP. Prevention and control of schistosomiasis: a current perspective. Res Rep Trop Med. 2014; 2014(5): 65-75.

5. Ding-Feng S. Defining pharmacology of natural products in the 21 st century - Challenge on multiple fronts. Front Pharmacol. 2010; 2010: 1-5.

6. Tavares JF, Silva MVB, Queiroga KF, Martins RM, Silva TMS, Camara CA, et al. Composition and molluscicidal properties of essential oils from leaves of Xylopia langsdorffiana A. St. Hil. et Tul. (Annonaceae). J Essent Oil Res. 2007; 19(3): 282-4. 
7. Donsì F, Ferrar G. Essential oil nanoemulsions as antimicrobial agents in food. J Biotechnol. 2016; 233: 106-20.

8. Jaiswal M, Dudhe R, Sharma PK. Nanoemulsion: an advanced mode of drug delivery system. 3 Biotech. 2015; 5(2): 123-7.

9. Sagalowicz L, Leser ME. Delivery systems for liquid food products. Curr Opin Colloid Interface Sci. 2010; 15: 61-72.

10. Campos VEB, Ricci-Júnior E, Mansur CRE. Nanoemulsions as delivery systems for lipophilic drugs. J Nanosci Nanotechnol. 2012; 11(3): 2881-90.

11. Trommer H, Neubert HR. Overcoming the stratum corneum: the modulation of skin penetration: a review. Skin Pharmacol Physiol. 2006; 19: 106-21.

12. Santos MG, Fevereiro PCA, Reis GL, Barcelos JI. Recursos vegetais da restinga de Carapebus, Rio de Janeiro, Brasil. Rev Biol Neotrop. 2009; 6(1): 35-54.

13. Maas P, Lobão A, Rainer H. Annonaceae. In: Lista de espécies da flora do Brasil. Jardim Botânico do Rio de Janeiro. 2015. Available from: http://floradobrasil.jbrj.gov.br/jabot/floradobrasil/FB110580/.

14. van den Dool H, Kratz PD. A generalization of the retention index system including linear temperature programmed gas-liquid partition chromatography. J Chromatogr A. 1963; 11: 463-71.

15. Adams RP. Identification of essential oil components by gas chromatography/mass spectrometry. 4th ed. Carol Stream: Allured Publishing; 2007.

16. Ostertag F, Weiss J, McClements DJ. Low-energy formation of edible nanoemulsions: factors influencing droplet size produced by emulsion phase inversion. J Colloid Interface Sci. 2012; 388: 95-102.

17. Santos JAA, Cavalcante VP, Rangel LS, Leite JCVA, Faria RX. A new technique using low volumes: a new technique to assess the molluscicidal activity using low volumes. J Evid Based Complementary Altern Med. 2017; 2017: 10 pp. doi: 10.1155/2017/3673197.

18. Karioti A, Hadjipavilou-Litina D, Mensah MLK, Fleischer TC, Skaltsa $\mathrm{H}$. Composition and antioxidant activity of the essencial oils of
Xylopia aethiopica leaves, stem bark, root bark, and fresh and dried fruits, growing in Ghana. J Agric Food Chem. 2004; 52: 8094-8098.

19. Lago JHG, Ávila Jr PA, Moreno PHR, Limberger RP, Apel MA, Henriques AT. Analysis, comparison and variation on the chemical composition from the leaf volatile oil of Xylopia aromatica. Biochem Syst Ecol. 2003; 31: 669-72.

20. Yapi TC, Boti JB, Ahibo CA, Bighelli A, Castola V, Casanova $\mathrm{J}$, et al. Chemical variability of the leaf essential oil of Xylopia aethiopica (Dunal) A. Rich. from Côte D'Ivoire. Chem Biodivers. 2012; 9(12): 2802-09.

21. Brophy JJ, Goldsack RJ, Forster PI. The essential oils of the Australian species of Xylopia (Annonaceae). J Essent Oil Res. 2011; 10(5): 469-72.

22. Silva L, Oniki GH, Agripino DG, Moreno PRH, Young MCM, Mayworm MAS, et al. Biciclogermacreno, resveratrol e atividade antifúngica em extratos de folhas de Cissus verticillata (L.) Nicolson \& Jarvis (Vitaceae). Rev Bras Farmacog. 2007; 17(3): 361-7.

23. Constantin MB, Sartorelli P, Limberger R, Henriques AT, Steppe M, Ferreira MJP, et al. Essential oils from Piper cernuum and Piper regnellii: antimicrobial activities and analysis by $\mathrm{CG} / \mathrm{MS}$ and C-NMR. Planta Med. 2001; 63: 771-3.

24. Cysne JB, Canuto KM, Pessoa ODL, Nunes EP, Silveira ER. Leaf essential oils of four Piper species from the state of Ceará - Northeast of Brazil. J Braz Chem Soc. 2005; 16(6b): 1378-81.

25. Nishino C, Tobin TR, Bowers WS. Electro antennogram responses of the American cockroach to germacrene D sex pheromone mimic. J Insect Physiol. 1977; 1910(77): 90282-7.

26. Rostelien T, Borg-Karlson AK, Faldt J, Jacobson U, Mustaparta $\mathrm{H}$. The plant sesquiterpene germacrene $\mathrm{D}$ specifically activates a major type of antennal receptor neuron of the tobacco budworm moth heliothis. Chemical Senses. 2000; 25(2): 141-8.

27. Chang Y, McLandsborough L, McClements DJ. Physicochemical properties and antimicrobial efficacy of carvacrol nanoemulsions formed by spontaneous emulsification. J Agric Food Chem. 2013; 61(37): 8906-13. 